\title{
Ewa Kaja
}

Uniwersytet im. Adama Mickiewicza w Poznaniu

\section{Unia Europejska na śródziemnomorskiej „scenie”}

Role Unii Europejskiej w regionie

Afryki Pólnocnej i Bliskiego Wschodu

Justyna Zając

Poznań 2012, ss. 360.

W granicami - tu przede wszystkim państwa z jej najbliższego otoczenia - były dobrze zarządzane oraz pozostawały z Unią w bliskich stosunkach opartych na kooperacji. Z jednej strony bowiem kolejne rozszerzenia wzmacniają wewnętrzne bezpieczeństwo Unii, z drugiej zaś zbliżają ją do regionów niestabilnych. „Sąsiedzi zaangażowani w gwałtowne konflikty, słabe państwa, w których na dużą skalę występuje przestępczość zorganizowana, wzrost zaburzeń w funkcjonowaniu społeczeństw lub gwałtowny wzrost populacji w pobliżu naszych (unijnych - przyp. red.) granic - wszystko to powoduje problemy dla Europy". Mając na uwadze sąsiadów z basenu Morza Śródziemnego, Strategia Bezpieczeństwa mówi o „strategicznym priorytecie” dla Europy, którym jest rozwiązanie konfliktu arabsko-izraelskiego, a także o konieczności stałego kontaktu z partnerami śródziemnomorskimi, do którego przyczynić ma się „skuteczniejsza współpraca gospodarcza, obronna i kulturalna w ramach procesu barcelońskiego"2.

O strategicznym znaczeniu regionu Afryki Północnej i Bliskiego Wschodu dla bezpieczeństwa europejskiego jest również przekonana Justyna Zając, której rozprawa habilitacyjna stanowi przedmiot niniejszej recenzji. Jej autorka dowodzi, że powstała w 1993 r. Unia Europejska zaczęła przejawiać coraz większe ambicje, by stać się aktywnym graczem/aktorem stosunków międzynarodowych, czego

${ }^{1}$ Bezpieczna Europa w lepszym świecie - Europejska Strategia Bezpieczeństwa, 12 grudnia 2003 roku, http://consilium.europa.eu/uedocs/cmsUpload/o31208ESSIIPL. pdf, 14.03.2013 r.

${ }^{2}$ Ibidem. 
dowodem było powołanie Traktatem z Maastricht Wspólnej Polityki Zagranicznej i Bezpieczeństwa, a także wykorzystanie polityk wspólnotowych do realizacji wyznaczonych celów strategicznych w polityce zagranicznej (s. 9). Jednakże jak zauważa, pierwsze wspólne działania państw Wspólnot wobec omawianego regionu zostały zainicjowane jeszcze przed formalnym powstaniem Unii Europejskiej, zaś od $1995 \mathrm{r}$. (powołanie Partnerstwa Eurośrodziemnomorskiego) można mówić o początku intencjonalnych i zinstytucjonalizowanych form współpracy i programów wobec tego strategicznego dla Unii regionu.

Omawiana praca składa się z dziewięciu rozdziałów, stanowiących efekt wieloletnich badań autorki nad prezentowaną tematyką. Jest to wnikliwa politologiczna analiza aktywności Unii Europejskiej, jej interesów, celów i wizji samej siebie w regionie Afryki Północnej i Bliskiego Wschodu, tak ważkim dla bezpieczeństwa Europy i świata, szczególnie w kontekście niedawnych wydarzeń rewolucyjnych w tym obszarze.

Istotnym walorem pracy jest zaproponowane przez J. Zając podejście teoretyczne, służące analizie zaangażowania Unii w omawianym obszarze. W rozdziale pierwszym pracy autorka wnikliwie omawia kategorię „ról międzynarodowych” począwszy od konceptualizacji pojęcia, poprzez uwarunkowania zewnętrzne i wewnętrzne ról oraz ich typologie, aż po efektywność ról. Autorka dowodzi, że stworzona przez Kalevi Holstiego w końcu lat 6o. XX w. koncepcja „ról międzynarodowych" państw (narodów), rozwijana w późniejszych latach przez jego kontynuatorów, stanowi przydatne narzędzie analizy oddziaływań międzynarodowych także bytów ponadnarodowych, tu Unii Europejskiej. Przekonuje, że posiadanie przez Unię podmiotowości międzynarodowej pozwala na odniesienie również i do niej kategorii „ról międzynarodowych", a definiowanie przez Unię odgrywanych przez siebie ról wpływa na kształt jej polityki zewnętrznej oraz na jej zachowanie w środowisku międzynarodowym (s. 44).

Prekursorski charakter ma wprowadzenie przez autorkę kategorii „efektywności ról międzynarodowych”, którą rozumie jako „skuteczność realizacji wytyczonego celu przy uwzględnieniu [jego - przyp. E. K.] kosztów" (s. 39). Jednakże J. Zając podkreśla, że to zadanie trudne. Trudność ta wynika z zauważanych przez autorkę pułapek napotykanych przy próbie oceny efektywności ról międzynarodowych. Są one efektem znacznej subiektywności osądu dokonywanego każdorazowo przez badacza, który może spotkać się z zarzutem o jego ograniczoną wartość naukową. Celem ograniczenia tych zarzutów autorka 
zaprezentowała komplementarne, jej zdaniem, czynniki determinujące efektywność ról międzynarodowych, tj. racjonalność koncepcji, umiejętność i konsekwencja w jej realizowaniu, stopień jej realizacji oraz poziom aprobaty roli przez jej adresatów (s. 39). Niemniej, słabość podejścia przejawia się tym, że pomimo zaprezentowania kryteriów oceny efektywności ról międzynarodowych odgrywanych przez Unię Europejską, autorka nie zaproponowała katalogu wskaźników oceny do każdego z przyjętych kryteriów, które mogłyby zmniejszyć zarzuty co do nadmiernego subiektywizmu i do jej małej warności naukowej takiej analizy.

W części poświęconej uwarunkowaniom ról międzynarodowych Unii Europejskiej (rozdział drugi), autorka wskazuje na najważniejsze determinanty kształtujące koncepcje ról międzynarodowych Unii. Obok czynników ilościowych, które wpływają na pozycję Unii Europejskiej na arenie międzynarodowej, szczególne znaczenie przypisuje tożsamości międzynarodowej Unii Europejskiej. Zdaniem Autorki, Unia znajduje się obecnie w fazie definiowania zarówno swojej tożsamości wewnętrznej, jak i zewnętrznej, którą rozumie jako „odrębność wobec innych podmiotów międzynarodowych” (s. 58). Na tak rozumianą tożsamość składają się wykształtowane normy i wartości, a także charakterystyczny dla Unii mechanizm instytucjonalny, które z kolei znajdują przełożenie w wyborze celów, zasad i metod polityki zewnętrznej (s. 58).

Zasadniczą część publikacji zajmuje niezwykle szczegółowe omówienie ról międzynarodowych, jakie Unia Europejska spełnia w obszarze basenu Morza Śródziemnego. Autorka wymienia tu: rolę aktywnego aktora w rozwiązywaniu konfliktu arabsko-izraelskiego, rolę promotora środków budowy zaufania, partnerstwa i bezpieczeństwa oraz rozbrojenia, rolę promotora reform ekonomicznych i zrównoważonego rozwoju regionu oraz rolę propagatora wartości demokratycznych, praw człowieka i dialogu międzykulturowego. Autorka dowodzi, że jednoczesne wypełnianie przez Unię Europejską wymienionych powyżej ról, świadczy o znaczeniu regionu dla unijnej polityki zagranicznej, a także o potrzebie wielopłaszczyznowego zaangażowania Unii w tak niestabilnym obszarze. Dalekosiężnym celem podejmowania przez Unię działań w omawianym regionie jest zapewnienie w nim „pokoju, stabilności i dobrobytu”, co zgodnie z literą Europejskiej Strategii Bezpieczeństwa, ma przyczynić się do zwiększenia bezpieczeństwa samej Unii i realizacji jej interesów. Jednakże, jak wskazuje autorka, nie będzie to możliwe bez trwałego zakończenia konfliktu izraelsko- 
-palestyńskiego, oraz z wyłączeniem gruntownych reform gospodarczych, politycznych i społecznych w państwach regionu. Nie dziwi zatem znaczne wsparcie polityczne, finansowe i techniczne ze strony Unii na rzecz wspomnianych reform. Celem realizacji zadeklarowanych ról Unia Europejska utworzyła instrumenty finansowe, początkowo program MEDA (1995-2007), który w 2007 r. został zastąpiony przez Europejski Instrument Partnerstwa i Sąsiedztwa (s. 122-130).

J. Zając podkreśla, że efektywne kształtowanie i wypełnianie przez Unię ról w regionie nie będzie możliwe bez dogłębnej analizy sytuacji wewnętrznej w poszczególnych jego państwach. Autorka omawia zatem główne problemy i wyzwania omawianego obszaru, co stanowi niewątpliwy atut książki. Skupia się na historycznych związkach Europy z Afryką Północną i Bliskim Wschodem (s. 66-72), na sytuacji wewnętrznej w państwach regionu, w tym ich niestabilności politycznej, niedemokratycznych rządach oraz trudnej sytuacji politycznej i gospodarczej (s. 72-83). Ponadto wskazuje na wyzwania i zagrożenia generowane w regionie, które wpływają na bezpieczeństwo europejskie, tj. konflikt arabsko-izraelski (s. 84-87), nielegalne migracje (s. 87-90), fundamentalizm i terroryzm islamski (s. 90-92), degradacja środowiska naturalnego (s. 92-94) oraz zagrożenia militarne (s. 94-95). Jednakże należy zauważyć, praca została ukończona w 2009 r., dlatego też część informacji w książce, z uwagi na wydarzenia tzw. rewolucji północnoafrykańskiej, może okazać się zdezaktualizowana. Niemniej jednak omówione przez autorkę kwestie ukazują jej szeroką wiedzę na temat regionu, która została przekazana w sposób prosty, ale bez nadmiernego uproszczenia mogącego stanowić zarzut wobec pracy.

Klamrą spinającą przeprowadzonej przez autorkę analizy ról międzynarodowych Unii Europejskiej w obszarze Afryki Północnej i Bliskiego Wschodu jest ocena ich efektywności. Jak zauważa, efektywność ta nie jest duża (s. 274). Jest to konsekwencją rozbieżności między rolami deklarowanymi przez stronę unijną a rolami oczekiwanymi przez państwa regionu, a także niekonsekwencji w realizacji przez Unię koncepcji ról (s. 275). „Koncepcja Unii Europejskiej, przewidująca odgrywanie wielu ról jednocześnie (...) jest zgodna z interesami UE, jej tożsamością międzynarodową oraz środkami, jakimi dysponuje. Nie jest jednak zgodna z oczekiwaniami państw północnoafrykańskich i bliskowschodnich (...)" (s. 275).

Publikacja J. Zając stanowi nowatorską, ważną i potrzebą analizę ról i polityki Unii Europejskiej wobec regionu Afryki Północnej i Bliskiego Wschodu, tak ważkiego z punktu widzenia bezpieczeństwa 
Europy. W sposób spójny i wynikowy omawia złożoną problematykę aktywności międzynarodowej Unii Europejskiej. Systematyzuje wiedzę na temat problemów i oczekiwań, które wobec Unii wystosowują państwa basenu Morza Śródziemnego. Z kolei nowatorskie zastosowanie teorii ról międzynarodowych jako modelu analizy polityki zagranicznej Unii Europejskiej sprawia, że wartość merytoryczną pracy należy ocenić wysoko.

\section{NOTA O AUTORCE}

Ewa Kaja [ewa.kaja@amu.edu.pl] - magister politologii (2009) w Uniwersytecie Mikołaja Kopernika w Toruniu, obecnie doktorantka na WNPiD UAM. Jej zainteresowania naukowe obejmują przede wszystkim teorię stosunków międzynarodowych, problematykę aktywności międzynarodowej Unii Europejskiej, głównie w kontekście odgrywanych przez nią ról międzynarodowych oraz zagadnienie „międzyrządowego liberalizmu” Unii Europejskiej w procesie podejmowania przez nią decyzji. 